\title{
Child Soldiers in Genocidal Regimes: The Cases of the Khmer Rouge and the Hutu Power
}

\author{
Péter KLEMENSITS, ${ }^{1}$ Ráchel CZIRJÁK²
}

\begin{abstract}
Genocide is one of the worst things one can imagine throughout the history of humanity. But in the cases of Cambodia and Rwanda this was even more serious as children were used as instruments of the massacres. Both the Khmer Rouge and the Hutu regime had their specific reasons for this act. The number of victims surpasses the millions, who either lost their lives, or suffered from various kinds of violence, because the young perpetrators were also victims, who carry the invisible scars in their souls. These historical examples are warnings for the international community to be active in situations like these, and stand up for the defenceless ones.
\end{abstract}

Keywords: Khmer Rouge, Hutu, Tutsi, genocide, child soldiers

\section{Introduction}

At the end of the $20^{\text {th }}$ century one of history's most brutal genocides took place in Southeast Asia and Sub-Saharan Africa. Between 1975 and 1978, the Khmer Rouge in Cambodia, then in 1994, the Hutu regime in Rwanda, together murdered approximately 2.5 million people. ${ }^{3}$ In both countries, the armies of the ruling regime took part actively in the atrocities, which largely have been exposed by now. However, it is less known that due to the regime's policies tens of thousands of children were indoctrinated and trained to serve as child soldiers and became perpetrators of the mass killings. ${ }^{4}$ Unfortunately, in the current world, mainly in developing countries, the use of children as soldiers is still widespread and the problem needs more attention from the international community. Actually, the phenomenon of child soldiery became a new threat to our security in the $21^{\text {st }}$ century. [4] This article examines two extreme cases of child soldiering in Cambodia and Rwanda, where the genocidal regimes, committing their crimes, did not spare the future generations as well. The presentation of these historical examples may help to understand better the problem of child soldiery not only in the past, but in the future too.

1 Ph.D., Senior Analyst, Geopolitical Institute of South-Southeast Asia, Pallas Athéné Foundation; e-mail: klemensits.peter@pageobudapest.hu

2 Junior Analyst, Geopolitical Institute of Africa, Pallas Athéné Foundation; e-mail: czirjak.rahel@ pageobudapest.hu

3 In Cambodia, the death toll can be estimated at 1.7 million and in Rwanda at 800,000. [1] [2]

4 The internationally agreed definition of child soldier can be found in the Paris Principles and Guidelines on Children Associated with Armed Forces or Armed Groups of 2007: “A child associated with an armed force or armed group (child soldier) is any person below 18 years of age who is, or who has been, recruited or used by an armed force or armed group in any capacity, including but not limited to children, boys and girls, used as fighters, cooks, porters, messengers, spies or for sexual purposes. It does not only refer to a child who is taking or has taken a direct part in hostilities.” [3] 


\section{The Kampuchean Revolutionary Army}

The Khmer Rouge, under the leadership of Pol Pot, the General Secretary of the Cambodian Communist Party had started to revolt against the Sihanouk administration in the 1960s, then after the fall of the Prince in 1970, continued the fight against the US backed Lon Nol government. In the context of the Vietnam War, China and North Vietnam supported the Khmer revolution, thus in spite of the US bombing and the financial-military aid received by Lon Nol, by April 1975, the Khmer Rouge victory became reality. The Ultra Maoist regime set about to transform the country thoroughly at once, for which the loyalty of the army were needed. Between 1975 and 1978, the Communist Party, through the use of armed forces did everything to exterminate the enemies of the revolution, inside and outside of the country as well. Finally, from 1976 the clashes with Vietnam become continuous, and two years later the attacking Vietnamese army caused the overthrow of the regime. ${ }^{5}$ [5] The unified Kampuchean Revolutionary Army came into being only in 1976, under the overall command of Son Sen, the Minister of Defence and the Chief of the General Staff. The army consisted of more than 72,000 soldiers in 9 divisions, as regular troops. Beyond that, there were the regional troops and militias in the zone, region and district level. [6]

The weapons and munitions flowed from China and Vietnam, therefore the Khmer commanders just had to concentrate on the drafting and training of the troops. In accordance with the official policy of the communist party, the poor and the lower middle class peasants made up 98\% of the soldiers, as they were to be the bases of the rural revolution, imagined by Pol Pot. ${ }^{6}$ [7] In the first half of the 1970s, people from the remote villages and mountains volunteered for military service in the ranks of the Khmer Rouge, conscription was only later introduced in consequence of the serious losses suffered on the battlefields. After the victory, everyone had to serve the revolution: the people from the cities ("new people"), like former soldiers, intellectuals, factory workers and other "enemies" were employed in agriculture, while the poor destitute were recruited for cadres in the army and the security forces.

\section{Children in the Armed Forces}

From the beginning, the Khmer Rouge considered the youth within the lowest social classes as the core force implementing the revolution. As Pol Pot declared: "It is the youth of today who will take up the revolutionary tasks of tomorrow.” [8: 16] The Khmer leader, like Mao Zedong during the Great Leap Forward and the Cultural Revolution, turned to the youth whose role in the revolution was to be the "dictatorial instrument of the party." [9: 5]

In theory, the basic education of the youth was compulsory, but during the rule of the Khmer Rouge illiteracy rates remained high as indoctrination in communist ideology was given priority and the need to serve in the armed forces became imperative. The young children in most cases were taught the use of small arms and the laying of landmines. ${ }^{7}$ Often

5 Following the fall of the Khmer Rouge administration, Pol Pot and his army retreated to the Thai border and remained as a considerable military force until the middle of the 1990s.

6 The General Secretary promptly realized that the less educated poor are the perfect candidates to follow orders without questioning and fight loyally under the guidance of the party.

7 Children in general were used as forced labour as well and those who refused military service were sent for re-education at working sites for example digging canals, or simply tortured and executed with their family members too. 
conscription concerned 10-12 year-olds, who after indoctrination were to be the most brutal cadres of the regime at the ages of 12-15. There are no records available for how many children were used as combatants in Cambodia, but their numbers can be estimated as tens of thousands during the 1970s and 1980s. ${ }^{8}$ For the brutal Khmer Rouge regime the youth were the perfect soldiers as "it is [...] easy for the commanders to give orders because the children did not have a conscience and are illiterate [...] they don't know what is good what is bad. So, they simply follow the orders the commanders give them.” [10: 28]

Child soldiers in possession of small arms could control and intimidate the civil unarmed masses, but the military knowledge they mastered and their physical abilities did not make them eligible to become an efficient army in the battlefield, though this did not cause anxiety for Pol Pot and his entourage. During the siege of Phnom Penh in 1973, the young Khmer Rouge army already suffered incredible losses which demonstrated the leadership's total disregard for the lives of their men. Later against the Vietnamese army this attitude did not alter, thus the masses of the children were to be nothing other than just cannon fodder in the eyes of their superiors. [11]

According to the extreme communist ideology, the Khmer Rouge did not draw distinction between young males and females and recruited girls in much greater numbers than the other combatting factions. Recent studies suggest that in the world presently, around $40 \%$ of all child soldiers are female, but in Cambodia during the 1970s this rate was probably higher. [12] Cambodian girls could have been valued similarly to the African ones: they were perceived "as highly obedient and easily manipulated [...] and ensure a constant pool of forced and compliant labour." "12] Due to the latest research, now it is evident, that young women played a significant role on every level of the Khmer Rouge administration, even if in the past, it was understated.

\section{Child Soldiers: Perpetrators and Victims}

Child soldiers in Cambodia can no doubt can be seen as victims of the brutal regime, who after indoctrination could be turn into perpetrators of the mass killing as well. There is no exact numerical data of the children who participated in the atrocities, let alone the young girls, but the survivors accounts correspond in this aspect, that the average ages of the security force and the army personnel were especially young. The personal stories, through the recollections of some former child soldiers may help to understand the human tragedy that was played out in full during the Khmer Rouge in Cambodia.

As a result of her memoirs, the story of Loung Ung became known all over the world. ${ }^{10}$ The 7 year old girl was taken from her family (previously her parents were killed by the Khmer Rouge) to be trained as a child soldier, but she survived the regime and settled down in the USA with her eldest brother. Her own records demonstrated clearly the ordeal the children went through: "I was a very angry kid. I was so angry the supervisor at one of

8 Still in the middle of the 1990s, the Khmer Rouge army consisted of approximately 2,000 child soldiers. [13]

9 Little girls can be used in messenger, reconnaissance and supplier functions much more easily than boys, because they do not arouse the enemy's suspicion.

10 UNG, L.: First They Killed My Father. New York, Harper Collins, 2006.; UNG, L.: Lucky Child: The Daughter of Cambodia Reunites with her Sister She Left Behind. New York, Harper Collins, 2010.; UNG L.: Lulu in the Sky: The Daughter of Cambodia Finds Love, Healing and Double Happiness. New York, Harper Collins, 2012. 
the orphanage camps picked me out of many other children to go and be trained as a child soldier. [...] I was given a stick to hit people. [...] Instead of learning about compassion and joy and kindness, I was taught to hate. I was taught to kill. [...] Because the children of the Khmer Rouge were the saviours of the future, and you all wanted us dead. I grew up with that [...] I grew up thinking you all gonna kill me.” [13: 3-4] The other famous narrative is that of Aki Ra, whose parents were also murdered by the Khmer Rouge, and at the age of 10 he was conscripted into the army where he became familiar with landmines. In 1985 he was captured by the Vietnamese, then 4 years later was drafted by the Cambodian Army. Finally, from 1992 with the help of the UN he dedicated his life to clearing mines in his country. ${ }^{11}$ He remembers the times with the Khmer Rouge as "We believed what they told us, as we didn’t have any choice [...] [and] I didn’t know anything of the outside world.” [14] Hong A. Chork one of the co-author of the book Children of Cambodia's Killing Fields: Memoirs by Survivors, recalled that as a little child he had to carry munitions for the troops thus "[...] my childhood was lost during those years. [... I I will never be able to feel the peace that I did before I turned six.” [15: 128]

The recollections of the combatants of the elite Khmer Rouge Division 703 are also revealing. This was the army formation guarding the most infamous Tuol Sleng detention centre and is responsible for numberless killings and tortures. ${ }^{12}$ In the early stage of the revolution, poverty and hatred against the Lon Nol government were adequate stimulus for many children to join the communist army. As Top Launh recalled: "I was poor and orphaned of my father from the age of nine. I lived with my mother and four sisters. My family life worsened from one day to the next. Combine that with my belief in the propaganda of the Khmer Rouge, and that is why in 1973 when I was fourteen years old, I volunteered to join the army." [7: 13-14] Later the conscription still could not been avoided. Ieuv Lay stated that "Since all members had been drafted into military service, in late 1973 the sub-district chief selected me for the region army like all the others. Then, whether I wanted to or not, I forced myself to join the military. If I had not done as assigned, the village chief would have persecuted me and my family.” [7: 18]

Many of these Khmer Rouge child soldiers were involved in the atrocities as well. Tuy Kin, a former "red female combatant" of the Division 12, who was drafted at age 14, took part in the battles until the capture of Phnom Penh, then became the member of the guard securing the Tuol Sleng Prison. Although she has insisted that she never killed people, she was sentenced to 18 months of prison for the involvement in the killing of 300 prisoners. [14] However, there are many more former child soldiers in Cambodia, who escaped from justice and have never been held accountable for their acts.

\section{The Killing Machine of Genocide in Rwanda}

For the public interest, Rwanda was almost unknown until 1994, when the country drew the world's attention: in a few months, hundreds of thousands of people lost their lives in massacres. But the media often reported mistakenly about the events as the exacerbation of ancient tribal enmity. In reality, it was a consciously planned action by the official government. The

11 Between 1992 and 2007 he personally defused about 50,000 mines.

12 In the Tuol Sleng or S-21 security prison approximately 20,000 people were executed during the rule of Pol Pot. 
Habyarimana-led Hutu government, which had been in power since 1973, was becoming more and more extremist, as the economic and political situation was worsening. For them, the final solution was the total extermination of the Tutsi population in Rwanda.

Between 1990 and 1992, Rwanda doubled its spending on weapons - and as a result the IMF and the World Bank suspended granting part of their aid. [17] A vast amount of machetes was imported into the country, ${ }^{13}$ which became the genocide's notorious weapon, as most of the murders were carried out with them. [18]

In 1993, a nationwide self-defence program was announced, where the (Hutu) population was armed, they were trained to use firearms and also involved in local patrol services. [18] The genocide was implemented by, in addition to the trained population, the State Army (Rwandan Armed Forces - Forces Armées Rwandaises [FAR]), the police, the political parties and their militias. Among the latter, perhaps the most notorious was an extremist paramilitary organization, the Interahamwe, established as the youth organization of the ruling party.

The militia held three week long trainings in Rwandese military camps, for nearly 2,000 people, who allegedly were so well-prepared that 40 of them could kill 1,000 Tutsis in twenty minutes. [19] Roméo Dallaire, the Force Commander of United Nations Assistance Mission for Rwanda (UNAMIR), said in his reminiscence that according to one of his informants, lots of children took part in the Interahamwe's training. The core group of the organization was supplied with weapons, and the children were given machetes during the preparation, the use of which did not cause them trouble because they used them during agricultural work. [20]

\section{Children as Participants of Genocide}

The Hutu leadership used thousands of children as instruments of genocide, who attended the slaughter as members of the army, or the Interahamwe, or were activated due to the general mobilization of the civilian population. But child soldiers - called "kadogo" in Swahili - did not fight only on the side of Hutus. A few days after April 6, the Rwandan Patriotic Front (Front Patriotique Rwandasi - FPR), led by Paul Kagame, attacked the genocidal regime and started to recapture the country. A lot of children were recruited into these guerrilla struggles as well. [21]

The use of children as soldiers basically resulted for two reasons. The first reason was that a significant and rapid increase took place in the number of military troops. Between 1990 and 1993 the number of the FAR soldiers increased from 5,000 to 28,000. Within the same period, the FPR swelled from 3,000 to 22,000 fighters. [20] With such a rate of expansion the presence of child soldiers is not surprising, since both sides' - especially the FPR - human resource requirements could only meet scarce resources. [20]

The other reason was - similarly to the Cambodian case - the children's emotional and mental immaturity, which made them more vulnerable to the government's hateful propaganda than adults. In addition, as in Rwanda children are taught to obey adults, they carried out orders more readily from the authorities than adults. [21]

The number of children participating in the genocide is estimated from 4,500-5,000. According to the Human Rights Watch, at least 5,000 children and juveniles have been arrested on genocide charges, [21] UN sources claim that from the 120,000 persons in custody, nearly

13 Between January 1993 and March 1994, a total of 581,000 kg, approximately enough quantity to arm the third of the Hutu adult male population. [18] 
4,500 had been younger than 18 years at the time of the genocide. [22] According to a study conducted by the Rwandese government in 1996, the number of kadogos were the same in the Tutsi army, fighting against the genocidial: 5,000 children were identified in the FPR, of whom 2,600 were younger than 15 years. [23]

The child soldiers functioned in many different areas in the Armed Forces. A Rwandese survey of 1995 interviewed eyewitnesses who said that among the children there were a number of persons who had to supervise the condemned ones to prevent their escape. Others worked as informers pretending to be orphans, and asked people to hide them. Then, a few days later they returned to the militia and revealed the names and whereabouts of those people. [24]

Witnesses also reported that the children participated in almost all crimes related to the genocide: they murdered, raped women and young girls, burnt and destroyed houses, robbed, and detected people hiding from military troops. [24] Dallaire also confirmed these statements: "By the time the genocide was in full swing by mid-April 1994, the Interahamwe were very visibly using the children to commit acts of killing and man roadblocks. The use of children was a deliberate tactical and strategic plan by the extremists.” [20]

The number of the badly effected people surpasses child soldiers and those who lost their lives or suffered any kind of abuse. Since the usage of child soldiers has long-term effects on society, as those children were socialised in violent circumstances, their reintegration into the society after the war has a slim chance. [25] Shadrack, who was a child soldier in the Interahamwe, reported the following from this period: "It was terrible! I was a member of the socalled 'Interahamwe' militia. We were backing the army to flush out anything that resembled a Tutsi. It seemed to me that almost everyone was taking part in the fighting. [...] In Gikondo suburb (Kigali), I remember going through hundreds of dead bodies with a FAL rifle. People were crying all the time, amid heavy gunfire and mortar shells.” [26: 56]

Gilbert B. was a kadogo in the FPR. He left primary school in 1993, and joined Kagame's army before the age of 14 . As a child soldier, he killed at least 3 people. Eventually he was demobilized in 1994. After he returned home to Gitarama, he came to know that his parents had been killed, and their house had been destroyed. In a rage, he killed a Hutu boy, who also was recruited by FPR, Gilbert's fourth victim. Gilbert said that he deeply regrets the murders, and he has been suffering from depression since his demobilization. He tried to live with his older sister, who has a family now, but he felt he did not belong to them, so he decided to live on the streets instead. "I had no place to live and I was alone in total isolation,"- he said. "I was going to commit suicide. I had so many problems. I was out of control. I had no one to help me. I could not see any solutions.” [21: 15]

\section{Conclusions}

The genocidal regimes in Cambodia and Rwanda alike brutally exploited the youth for their own purposes and committing the atrocities with the use of child soldiers were an acceptable solution for them. In Rwanda, the rival factions similarly drafted children in their armies, deliberately pressing them to become the tool of genocides. However only the reigning regimes used minors as the tools of violence, as the intimidated and tortured citizens were unable to put up resistance. In both cases the regimes clearly realized that the children were cheap and obedient servants and the losses they suffered were not under consideration. However, there 
P. KLEMENSITS, R. CZIRJÁK: Child Soldiers in Genocidal Regimes: The Cases of the Khmer Rouge...

is one distinction between Cambodia and Rwanda, for Pol Pot recruiting children (including little girls as well) was a core interest of the movement according to their extreme ideology. There was no such a policy for the Hutu Power only the scarce human resources led the regimes to this act. But it can be concluded without doubt, the children can be seen as perpetrators of the atrocities and victims of the regimes alike.

Unfortunately, at present there are still a lot of developing countries where the use of child soldiers is a common thing, so the international community has a lot to do to prevent the repetition of the Cambodian and Rwandan scenario.

\section{References}

[1] KIERNAN, B.: The Pol Pot Regime: Race, Power, and Genocide in Cambodia under the Khmer Rouge, 1975-1979. New Haven: Yale University Press, 2008.

[2] UNHCR: Genocide in Rwanda. Glendale: United Human Rights Council, 2000. www. unitedhumanrights.org/genocide/genocide_in_rwanda.htm (Downloaded: 166 2016)

[3] UNICEF: The Paris Principles. Paris Principles and Guidelines on Children Associated with Armed Forces or Armed Groups. New York: UNICEF, 2007. www.unicef.org/emerg/ files/ParisPrinciples310107English.pdf (Downloaded: 166 2016)

[4] SZIJJ D.: Children in Armed Conflicts - A general review of child soldiery, especially in the Democratic Republic of the Congo. AARMS, 92 (2010), 343-359.

[5] CHANDLER, D.: A History of Cambodia. Boulder: Westview Press, 2000.

[6] The Khmer Rouge National Army: Order of Battle, January 1976. New Haven: Yale University Cambodian Genocide Program, 1976. http://gsp.yale.edu/khmer-rouge-nationalarmy-order-battle-january-1976 (Downloaded: 166 2016)

[7] VANNAK, H.: The Khmer Rouge Division 703, From Victory to Self-destruction. Phnom Penh: Documentation Center of Cambodia, 2003. http://citeseerx.ist.psu.edu/viewdoc/ download?doi=10.1.1.139.6706\&rep=rep1\&type=pdf (Downloaded: 166 2016)

[8] PROCKNOW, G.: Khmer Rouge Pedagogy Indoctrinating Khmer Children for Violence. In. Searching for the True. Magazine of the Documentation Center of Cambodia. Special English Edition, Second Quarter, 2013.

[9] PROCKNOW, G: Khmer Rouge: Recruitment and Selection \& Training and Development. www.d.dccam.org/Projects/Genocide/pdf/KR_ RecruitmentSelectionTrainingDevelopmentRetention.pdf (Downloaded: 166 2016)

[10] ICRC: People on War. Country Report Cambodia, ICRC Worldwide Consultation on the Rules of War. Report by Greenberg Research Inc. Geneva: The International Committee of the Red Cross, 1999. www.icrc.org/eng/assets/files/other/cambodia.pdf (Downloaded: 166 2016)

[11] SHORT, P.: Pol Pot: Anatomy of a Nightmare. New York: Henry Holt and Company, 2005.

[12] KATZ, B. : Female Child Soldiers can be Victims of Abuse, Perpetrators of Violence. The New York Times, 48 (2015). http://nytlive.nytimes.com/womenintheworld/2015/08/04/ female-child-soldiers-can-be-victims-of-abuse-perpetrators-of-violence/ (Downloaded: 166 2016)

[13] BARNITZ, L., PATH, H., CATALIA, R. F.: Cambodia: Pol Pot's Legacy of Violence. Youth Advocate Program International Resource Paper, Case Study, 2001. http://yapi.org/wpcontent/uploads/2014/01/report-cambodia1.pdf (Downloaded: 166 2016) 
P. KLEMENSITS, R. CZIRJÁK: Child Soldiers in Genocidal Regimes: The Cases of the Khmer Rouge...

[14] SUMITRA: Former Khmer Rouge Soldier Has Spent the Last Two Decades Cleaning Cambodia of Mines, Alone and without Protection. odditycentral.com, January $15^{\text {th }} 2015$. www.odditycentral.com/news/former-khmer-rouge-child-soldier-has-spent-the-last-twodecades-cleaning-cambodia-of-mines-alone-and-without-protection.html (Downloaded: 166 2016)

[15] CHORK, H.: The Unplanned Journey. In. DePAUL, K., PRAN, D. (Eds.): Children of Cambodia's Killing Fields: Memoirs by Survivors. New York: Yale University Press, 1999.

[16] CRANE, B.: Female Cadres of the Khmer Rouge. The Phnom Penh Post, 18 (2015). www. phnompenhpost.com/post-weekend/female-cadres-khmer-rouge (Downloaded: 166 2016)

[17] T. HORVÁTH A.: Ruanda ’94: egy krízis történelmi háttere. Kül-Világ, 12 (2004). http://epa.oszk.hu/00000/00039/00002/thorvath.html (Downloaded 166 2016)

[18] BIEDERMANN ZS.: Genocídium és destabilizáció az afrikai nagy tavak régióban A konfliktusok gazdasági vetülete. Budapest, Pécs: Publikon Kiadó, 2015.

[19] CROS, M-F.: Jean Birara: 'The Belgians and French Could Have Stopped the Killing'. Rosslyn: Foreign Broadcast Information Service (FBIS), 1994.

[20] DALLAIRE, R., WHITMAN, S.: Preventing the Use of Child Soldiers, Preventing Genocide. UN Chronicle, LII 1-2 (2015). http://unchronicle.un.org/article/preventing-usechild-soldiers-preventing-genocide/ (Downloaded 166 2016)

[21] Lastin Wounds: Consequences of Genocide and War on Rwanda's Children. New York: Human Rights Watch, 156 (A) (2003), 1-106. www.hrw.org/reports/2003/rwanda0403/ rwanda0403.pdf (Downloaded 166 2016)

[22] UN: Report of the Special Representative of the Commission on Human Rights on the situation of human rights in Rwanda. UN Doc. A/55/269, August $4^{\text {th }} 2000$. www.un.org/ documents/ga/docs/55/a55269.pdf (Downloaded 166 2016)

[23] MLSA: Children in Difficult Circumstances: Policy and Plan of Action. Kigali: Ministry of Labor and Social Affairs, 1996.

[24] SCF: Children, genocide, and Justice: The Rwandan Perspectives on Culpability and Punishment for Children Accused of Crimes Associated with Genocide. Kanyarwanda: Save the Children Federation - USA in collaboration with Haguruka, and Kigali: LIPRODHOR, 1995.

[25] BESENYŐ J.: Hagyomány vagy újkori találmány? - A gyermekkatonaság. In. CSIZMADIA S., TARRÓSY I. (szerk.): Afrika ma - Tradíció, átalakulás, fejlődés. Pécs: IDResearch Kft., Publikon Kiadó, 2009.

[26] The Use of Children as Soldiers in Africa. A country analysis of child recruitment and participation in armed conflict. http://reliefweb.int/sites/reliefweb.int/files/resources/ The\%20Use\%20of\%20Children\%20as\%20Soldiers\%20in\%20Africa\%20report.pdf (Downloaded 166 2016) 